\title{
MISTRAL MISTRAL
}

Journal of Latin American Women's

Intellectual \& Cultural History

\section{The Performative Forum: Women, Body and Memory in the Foro de Escritores Chile}

Jèssica Pujol Duran, Universidad de Santiago de Chile

To cite this article: Jèssica Pujol Duran. 2021. "The Performative Forum: Women, Body and Memory in the Foro de Escritores Chile" Mistral: Journal of Latin American Women's Intellectual \& Cultural History 1 (1): 63-80, https://doi.org/10.21827/mistral.1.37509

\begin{abstract}
This article examines the contributions of three contemporary Chilean women poets, Cecilia Vicuña, Anamaría Briede and Luna Montenegro to the UK Writers Forum and its Chilean counterpart, El Foro de Escritores. In the early 2000s, these groups produced two ongoing workshops that focused on poetic experimentation and performance and valued the oral over the written word. Entering into dialogue with Charles Bernstein's analysis of the poetry reading, Erika Fischer-Lichte's performative turn in the arts, and Joseph Roach theorization of performance and memory, this article unravels Chilean women's poetics within a transnational context. It proposes that the value these women poets placed on aurality facilitated new engagement with Pre-Columbian cultures and languages as well as reconsiderations of the intimacy of the body and its linguistic representation.
\end{abstract}

\section{Keywords}

Aurality; Poetic performance; Writers Forum; Pre-Columbian languages; Chilean women poets; Memory 


\title{
The Performative Forum: Women, Body and Memory in the Foro de Escritores Chile
}

\author{
Jèssica Pujol Duran, \\ Universidad de Santiago de Chile
}

The Writers Forum emerged as a fortnightly poetry workshop and magazine in 1951, set up in the upstairs spaces of pubs and other London venues, where the attendees were encouraged to share their latest poetry through performance. This happened during a more general anglophone rediscovery of poetry readings (Bernstein), sound poetry (Cobbing) and the transformative power of speech, identified by Erika Fischer-Lichte as 'the performative turn in the arts' (Fischer-Lichte 2008, 24). Over a decade later, by 1963, the Forum developed into a small press of the same name; its founders, Bob Cobbing, Jeff Nuttall and John Rowan, decided to start the press to publish their own work and the work of artists and writers they admired such as John Cage, Allen Ginsberg and the poets of the British Poetry Revival (including Tom Raworth, Eric Mottram, Lee Harwood, Maggie O'Sullivan and Allen Fisher) outside of the constraints of the publishing industry.

In 2007 poet and critic Robert Sheppard regretted the lack of history of this group in his epilogue to When Bad Times Made for Good Poetry (Sheppard 2011, 215216), a call to arms that has seemingly lead to a growing body of work on the Writers Forum and its role in the shaping of the British Poetry Revival. ${ }^{1}$ However, little has yet been written about a late - but nonetheless paramount - contact between a group of Chilean poets, El Foro de Escritores (aka FDE), and the London Writers Forum. Reading the work of these particular Chilean poets - including Andrés Anwandter, Martín Gubbins, Luna Montenegro and Kurt Folch-alongside some of the regulars at the Forum gatherings, such as Cobbing, Fisher and O'Sullivan, one cannot fail to notice a significant cultural exchange between their poetics. Something that began as an 'immediate connection'-in Gubbins' words (Martín Gubbins, e-mail interview with the author, February 28, 2021) —ended up expanding into a series of collaborations and publications from the early 2000s in London and through 2003 and beyond in Santiago de Chile, in a spin-off of the London group founded by the poets Gubbins, Folch and Felipe Cussen.

One of the main connections between these Forums was their preference for the oral over the written word. They privileged the poetry reading for the contact the poet establishes with his or her work and the audience over the private, silent and lonely act of reading to oneself. Charles Bernstein, in the introduction to Close Listening: Poetry and the Performed Word (1998), criticises a historical preference for the written text over the poetry reading, stating that the poetry reading is 'a medium in its own right, a medium that has had a profound impact on twentieth-century poetry, and in particular

\footnotetext{
${ }^{1}$ New essays about the revival include Juha Virtanen's Poetry and Performance During the British Poetry Revival 1960-1980: Event and Effect. Cham: Palgrave Macmillan, 2017; Elizabeth-Jane Burnett's A Social Biography of Contemporary Innovative Poetry Communities. Cham: Palgrave Macmillan, 2017; Steve Willey's 'Locating the 1950s, Bob Cobbing's Poems and Places' in Boooook: The Life and Work of Bob Cobbing. Eds. William Cobbing and Rosie Cooper. London: Occasional Papers: 2015. 12-17, among others.
} 
the poetry of the second half of the century' (Bernstein 1998, 22). Considering how foundational the poetry reading was for these groups, it is important not only to document the events which took place during the sessions, but to essay critical readings on their significances for poetry, the individual poet, and the communal experience of reception that took place in the meetings. I find there is still a considerable amount of research to be done into the poetry readings and active collaborations between the London Writers Forum and the Foro de Escritores Chile, and my intention with this article is to start filling these gaps by focusing on three Chilean women poets who had direct and indirect contact with both Forums and whose work focuses on the aural aspects of the poem more than its written forms. This will serve to begin to unravel the collaborations and shared poetics of these avant-garde groupings, at the same time as addressing the roles women and aurality had in the sessions.

The poets I will address are Cecilia Vicuña (b. 1948), Anamaría Briede (b. 1971) and Luna Montenegro (b. 1973). As guests or active participants in both Forums, they share that interest in aurality, but I will argue that their poetics also unveil a concern for memory, especially collective memory related to rituals and the songs and languages of Pre-Columbian America, a specifically South American characteristic which I will explore in this article. I will look at Seis (FDE, 2005), a pamphlet which includes a well-documented Foro session that produced a CD featuring Vicuña, Jerome Rothenberg and Lorenzo Aillapán (the Mapuche Birdman) among others, as well as visual and poetic work by various of the regular artists; Cinco (FDE, 2005), another pamphlet which includes Anamaría Briede's visual poetry launched in one of the workshops which is also accompanied with a CD, and Catorce/Quince (FDE, 2006), an anthological pamphlet which features work by Luna Montenegro (this is the only publication that doesn't include a CD). Finally, I will also pay attention to the work behind the scenes of another Chilean female artist, Olaya Balcells, who edited and produced all these pamphlets turning them into beautiful objects.

\section{The Interdependence of Performance and Collective Memory}

The title of this section is taken from Joseph Roach's essay 'Culture and Performance in the Circum-Atlantic World' (1995), in which Roach states that in the study of English language and culture - and this could be applied to Spanish language and culture as well-literature is not sufficient because there are many cultural forms 'invested in speech, gesture, song, dance, storytelling, proverbs, rites, and rituals' (Roach 1995, 45) that cannot be fully understood without an active research into the oral experiences of the culture. He suggests that literacy and orality shouldn't be different fields of research as 'these modes of communication have produced one another interactively over time' (Roach 1995, 45) - they are entangled and to limit ourselves to the written word is to limit our knowledge of any culture. In order to fully represent language and culture, then, Roach suggests a 'rubric of performance' (Roach 1995, 46), as it is in the act of performance where we can best capture the singular amalgam of language(s) and culture(s) attached to a particular cultural production. The founder of the Writers Forum, the poet Bob Cobbing, whose experiments with sound and other media influenced this particular generation of Chilean poets, also saw literature as reductive for the understanding of poetry, for him it is a 'fundamental mistake to regard poetry as a branch of literature. It is not. It is best regarded as one of the performing arts' 
(Cobbing, 1985). ${ }^{2}$ Performance, or poetic performance, therefore, seems to be a better term to approach the characteristically oral and embodied forms that took place in these sessions and to start shaping an understanding of the singular amalgam of languages and cultures from South America these poets convey in their work.

With this in mind I will look at the publications Seis, Cinco and Catorce/Quince not as individual and complete literary instances but as works which represent a part of what was taking place at the Foro. Only if we take into account the whole experiencethe sessions and the publications - are we able to start seeing the interdependence Roach describes. It is not only the performances that bring back certain collective memories, but also the printing of these performances that documents or memorises what took place in the collective session. It is paradoxical because the performance, contrary to the printed pamphlet, cannot be reproduced identically twice; thus, how can we trust a memory that is always changing? According to Roach, this is precisely the value of the performance, it is in the reinvention of memory that a transformative experience emerges among the audience:

The paradox of the restoration of behavior resides in the phenomenon of repetition itself: no action or sequence of actions may be performed exactly the same way twice; they must be reinvented or recreated at each appearance. In this improvisatory behavioral space, memory reveals itself as imagination.

(Roach 1995, 46)

It is through this improvisatory process that the performer and the public are able to immerse themselves in the cultural experience. Through an analysis of the sessions and the strategies of the poets it can be seen that they understand culture as something vital, in constant movement and prone to be reimagined and reinvented, not as a static set of customs and rituals only accessible through the written text. The public or auditor, in this scenario, played an active role, as memories come more readily to them (Roach $1995,48)$ than to us, the readers, listeners or viewers of that pregnant moment. In the following sections I will therefore pay special attention to the visual and oral recordings of the sessions, as well as to private e-mail and voicemail accounts by some of the attendees. The publications, even if they represent what took place in the sessions, don't offer a substitution for the performances; the intention is to get a better understanding of the whole Writers Forum/Foro experience, and not limit it to its written products.

\section{Performing What Earth Feels}

Cecilia Vicuña writes: 'The true performance is that of our species on Earth: the way we cause suffering to others, the way we warm the atmosphere or cause other species to disappear. I cover myself with clouds to feel like the Earth feels' (Vicuña 2012, 98). In Vicuña's work the connection of body to nature is crucial; in her performances the real performance is that of mankind on Earth, she is a conductor between that human activity and the public present at the performance, giving back to humanity the memory of its own damage. As an artist born in Chile, conscious of its troubles and engaged

\footnotetext{
${ }^{2}$ In 'What the tape-recorder teaches the poet' (1985), a statement that refers to his radio broadcast 'The Electronic Voice’ (1983).
} 
with its politics, in her performances Vicuña intends to reimagine the damage colonization and neoliberalism have inflicted on the land: from the constant occupation of indigenous territories to the selling of Araucanian wood to the United States or the privatization of water, the land which we know as Chile is under constant duress. Vicuña's connection to this suffering is through her body: 'lo personal es político' (Lynd 2015, 52) she says; thus the embodiment of these economic and political performances of man on Earth is a political embodiment. In her performances, more than speaking for or giving voice to the Mapuche (the indigenous people originally from the centre and south of Chile and part of Argentina) and other indigenous groups, she places herself in a liminal position in which she is 'neither here nor there' (Turner $2017,95)$ in Victor Turner's sense: a liminal place from which she is able to reinvent a collective memory of that damage.

The Foro session which was later transcribed and published as a pamphlet entitled Seis-i.e., the sixth publication of the Chilean group-is useful for the appreciation of what the artist means by performance. The session, which took place on the $13^{\text {th }}$ of November 2004 in Santiago's Bar Rapa Nui, opened with Lorenzo Aillapán (b. 1940), a Mapuche poet, actor, cinema producer, anthropologist and artisan, also known as ünümche or 'bird man' for his interpretations of birdsong. He first reminds the public of the Mapuche custom of holding an instrument, the trutruca (an instrument of communication with foreigners for the Mapuche people), and then starts playing it and reciting a chant combining Mapuche and Spanish. In this poem we already see the importance Earth has for the Mapuche culture: 'EL QUE TRABAJA LA TIERRA, / ESTARÁ REPLETO DE ALIMENTO. / GENTE DE OTRA COMARCA, / JAMÁS SE ADUEÑARÁ DE ESTE SUELO' (Vicuña et al. 2005, 10). And: 'DE TODAS LAS MELODÍAS Y CANCIONES DE LA TIERRA, / CAPTO SUS ESENCIAS / LA LEY DE LA GENTE QUE VIVE' (Vicuña et al. 2005, 11). On the one hand, poetic voice communicates a strong will to defend the land one works against usurpers from other counties; on the other hand, from the songs and melodies from Earth he 'captures its essences' and communicates them to the public, just like Vicuña does when she reproduces what the land feels in her performances.

After this opening, which performs the function of a rite of passage, Gubbins presents the workshop remembering Cobbing and their connections to the British Writers Forum, where,

todo era permitido, y por otro lado todo era, además, muy respetado, y de todo se sacaba enseñanzas. Yo creo que ese es el espíritu que nos reúne aquí ... y por eso nos interesó tanto estar aquí con ustedes, y con Cecilia particularmente, que es chilena, por lo que ella ha hecho en Chile desde los años sesenta, y en el extranjero, experimentando, llevando la poesía a distintos territorios, llevando la poesía a la tierra.

(Vicuña et al. 2005, 12)

Gubbins also associates Vicuña's poetry to the Earth. After Jerome Rothenberg's intervention, in which he sings a Seneca song in Iroquoian, Vicuña sings in order for the sun to come out. It is an unusual cold and cloudy Spring day, and her singing is meant to invoke the sun and all its power to shine and warm the poets gathered at the bar. Then, Aillapán joins with a song to greet the ancestors invoking the hills and Ricardo Castro, another Mapuche poet, invokes the frogs because 'las ranas hicieron 
que lloviera estos dos días' (Vicuña et al. 2005, 15), both contributing to Vicuña's petition.

After the chanting the group settles and, with reference to Rothenberg's presence, the poet Javier Tlum raises a pertinent question about the connection between ethnic poetry and experimental poetry:

¿cómo se logran atar esas dos puntas - que primero que nada vienen de dos mundos diferentes, el mundo de occidente y el mundo del origen de las tierras - el concepto de vanguardia, y el concepto étnico; cómo las dos puntas de la cuerda se logran unir en este trabajo etnopoético?

(Vicuña et al. 2005, 17)

Rothenberg is the author of the famous anthology Technicians of the Sacred (1967), which brought to the poetry of the anglophone North Americans knowledge of indigenous and intercultural poetries from around the world. The anthology had an important influence on the avant-garde poetry scenes of the 1960s in need of opening up to other traditions and forms of poetry (Davies 2020, 20-21). He replies that experimental poetry includes all types of poetry, and thus it also manifests an interest in the relations between their own Western tradition and that of very different cultures:

At a certain historical point we gave up the belief that our way of doing poetry and of practicing other arts, was the only way ... those of us that made that break came to think of themselves, of ourselves, as living in a single world ... one strategy that opened for us, was to invent new forms, new languages of our own. But another way was to listen and to try to understand the ways in which language and rhythm, music, dance and art would have arisen and been practiced in other places, everywhere ... we wanted to strike out in new directions, to find new ways of making poetry.

(Vicuña et al. 2005, 17)

Rothenberg's understanding of experimental poetry as a poetry that can borrow from other cultures in order to find new strategies for writing is not without its issues. In Technicians of the Sacred (1967), for instance, ritual texts from different cultures are presented in creative translation with comments that contextualise the texts and often compare them to contemporary North American avant-garde poems. This has been criticized by scholars such as Josef Horáček, for whom the format of the anthology 'obfuscates the historicity of their material by collecting and juxtaposing sources recorded by Westerners at different points in time across several centuries' (Horáček 2011, 170; in Davies 2020, 24). The transposition of rituals from indigenous cultures which have been subject to violent colonialism to the marketplace of the imperial centre could end up producing cultural appropriation rather than insight into these cultures; although, as Nia Davies points out, '[Rothenberg's] editorial and translation works have come to be seen by some in the field of indigenous and intercultural poetry studies as beneficial to endangered poetic cultures rather than detrimental, as they have resulted in the visibility of these poetic cultures' (Davies 2020, 24). Despite these on-going discussions, and answering to Rothenberg's reflections, Vicuña expresses that she doesn't completely agree with the way that ethnopoetics approaches the 'other': 
para mí la categoría de etnopoesía no es una categoría operante. Porque etno, ¿qué quiere decir? Etno quiere decir que hay un pueblo que nombra a otro como etno. Entonces, yo nunca tuve esa movida ¿te das cuenta? Yo siempre me consideré persona. Como dice mi amiga Graciela Huinao, ella nunca supo que era india, hasta que otro le dijo que ella era india. Entonces eso es como un punto de partida claro. ... Antonio Candio, un pensador brasilero ... había dicho que nosotros, los sudacas, ... encontramos como un punto común instantáneo, que no necesitaba teoría, que no necesitaba nada porque nosotros éramos ese punto de encuentro entre las culturas 'primitivas', originarias de América, y la vanguardia europea de comienzos del siglo XX.

(Vicuña et al. 2005, 19)

The 'sudaca' or South American view, according to Vicuña, cannot be that of the coloniser on the colonised or the colonised on the coloniser because they are criollos; they occupy that liminal or in-between space in which the native cultures of the Americas meet the European avant-gardes. Here Vicuña talks of her experience as a criolla, not about the aboriginal cultures of South America per se. Vicuna doesn't feel 'ethno-' because she doesn't consider herself as 'other'. In an interview with David Levi Strauss, she states this clearly: 'I am a mixed person, a person of two cultures. So I don't trust either - that is the reality. I use everything because I want to ask them all to remember' (Vicuña 1999, 20). According to Vicuña, otherness comes from outside, from someone seeing you as other. She feels she dwells in that in-between, in the same way she positions herself in-between the sufferings of their land and the rest of the world in order to remember. She recounts an anecdote of when she came across Technicians of the Sacred, just a year after its publication; she exclaims, 'inmediatamente supe que ese libro era para mí' (Vicuña et al. 2005, 20). She had previously read a much thinner book by Jorge Salamea, entitled Poesía Ignorada y Olvidada, written in the early sixties, and could draw a connection between the two books as proof of 'una conexión entre las búsquedas del Norte y del Sur' (Vicuña et al. 2005, 20). She concludes:

lo que tienen en común la poesía más originaria, la poesía 'antigua' de todo el planeta, no solamente de América, la poesía que se está haciendo hoy, es el hecho de que la poesía parte de lo que no sabe, y parte de una necesidad de estar en lo que uno no sabe, como un nuevo saber.

(Vicuña et al. 2005, 20)

Vicuña is looking for something relatable for all; poetry moves the poet from the unknown - and from a necessity to dwell in the unknown - to new understandings of the world. In this process, the poet works carefully with memory, building bridges between certain experimental understandings of poetry and the poetry of the ancestors of the land she inhabits on an anachronistic plane. Dagmar Bachraty states: 'La obra de Vicuña establece un cruce entre los idiomas del arte conceptual y los rezagos de una memoria ancestral, explotando de manera singular y compleja las potencias significativas de la anacronía.' (Bachraty 2019, 197). I read the poetic performances, 
readings, collaborations and listenings of the Foro as taking place in this anachronistic plane where different voices, cultures and times share a heterotopic space.

The poetic performance, for Vicuña, would bring back an ancestral memory, reimagined and transformative for both herself and the public. Towards the end of the session, after more singing, readings and discussion among the poets, Vicuña intervenes again with a song that, according to her, subverts an Andean tradition. She explains that a shepherdess once told her that she learnt to sing to scare the pumas, so the pumas didn't come to eat their sheep. She says what she does is different, but she wanted to tell this story so chants 'puedan chocar en el aire' (Vicuña et al. 2005, 32):

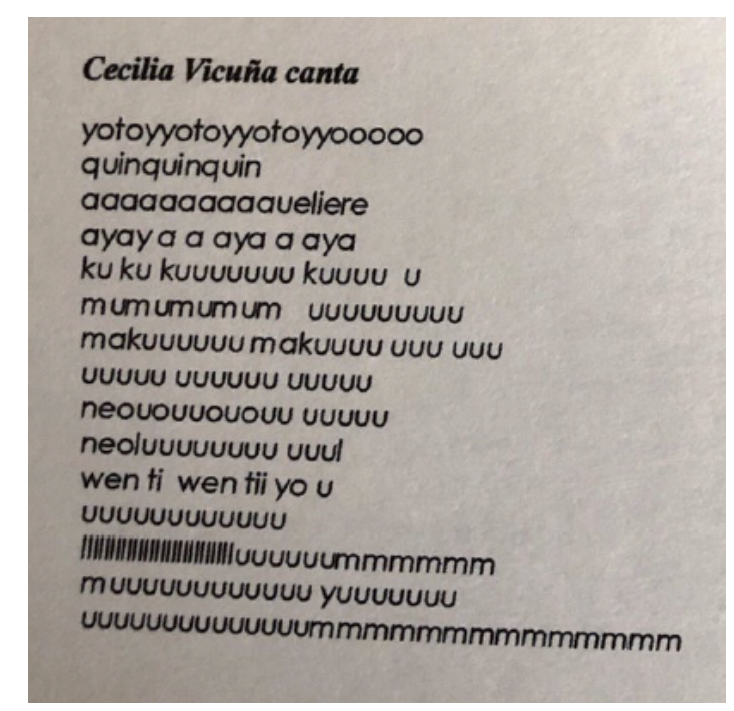

A song improvised by Vicuña and transcribed in Seis p. 32

Again, there is a reference to tradition but also a distancing from it, as her poetics are not based on passing on those memories faithfully; instead, she reinvents them, makes them clash in the air, and in that clashing the public experiences that transformation. As José Felipe Alvergue puts it: 'Vicuña's poetics of dissonance evokes a harmonious discordance with the politics of consensus while proposing new modes of expressing the collective' (Alvergue 2014, 208). At the end of the session the sun came out.

\section{A New Writing of the Body}

Anamaría Briede was also present at Vicuña's session and intervened with a performance in which she pulled an imaginary thread from her mouth with her fingers, placed it on a blank page in front of her, and then grabbed a pencil and started drawing a line and what looked like words without taking the pencil off the page (Vicuña et al. 2005, 34). The whole performance is in silence and contrasts with all the earlier singing and talking. This invisible thread could be compared to the quipus Vicuña works with, as both relate to communication. Quipus are knotted strings which were used by the Andean civilisations to gather information. In Vicuña's poem 'Palabra e Hilo / Word \& Thread' (1996), translated by Rosa Alcalá, threads represent words following the meaning of the ancient quipus: 
Word is thread and the thread is language. / Non-linear body. / A line associated to other lines. / A word once written risks becoming linear, / but word and thread exist on another dimensional plane. / Vibratory forms in space and in time. / Acts of union and separation. // The word is silence and sound. / The thread, fullness and emptiness. // ... // Is the word the conducting thread, or does thread conduct the word- / making? / Both lead to the centre of memory, a way of uniting and connecting. / A word carries another word as thread searches for thread. / A word is pregnant with other words and a thread contains / other threads within its interior.

(Vicuña 1996, 2-3)

'The word is silence and sound', although in the case of Briede's piece silence speaks over sound. She extracts a thread-word from her mouth, but no sound or clear sign emerges, just the gestures, reminding the public of the other side of the sign, the nonverbal movements which lead 'to the centre of memory'. Here, given the atmosphere created in the session, this invisible thread might represent the connection that ties all the poets present at the table together, as it conceptualises the transformation that is taking place there, from aural to written expression, from the performance to the printed pamphlet. Here the cyclical experience of the Foro is summarised by a silent and simple act that takes no longer than thirty seconds.

Briede was a young poet and artist by 2004, when she joined the Foro invited by Gubbins via Soledad Fariña, another Chilean poet and participant of the workshops, just after coming back from an art's residency in Münster (Germany). Briede soon became one of the central members of the Chilean group in 2005 publishing Cinco, Columna Vertebral del Cuerpo, the first time the Foro published the work of a woman. The pamphlet gathers visual work, identified by Briede as 'poemas diagramáticos' on the cover. It came out just before Vicuña's pamphlet, although contrary to Vicuña's, which consisted in the transcription and artwork produced in one single session, Briede's is a compilation of a long-term and more committed relationship with the group. Like Vicuña's pamphlet it includes a CD, entitled Altares Perforados.

This CD has seven tracks consisting of an intimate conversation between Briede (from Germany) and another imagined person who is on the other side of the Andes (Briede, WhatsApp audio message to the author, March 18, 2021) many of which include the sound of a pencil writing on a page, as in 'Sobre 1 Mesa' (1:27), where the only words we hear are 'sobrevuelo la escritura' and the rest are sounds of that pencil representing the sound of the body, but also creating 'a body of sound', according to Briede; or the sound of hands typing on a typewriter like in 'Tic Tic Tic Tac Trrr' (1:39), where we only hear the clatter of typing. The track that closes the album, '1 Sobre Blanco' (1:20), works as a manifesto for Briede's poetics. In this piece she mutters sentences such as: 'sobreguardar el testimonio de una lengua', 'anacronismo celular de las letras' and 'el resonar de estas teclas darán curso nuevo a esta nueva escritura del cuerpo', all of which suggest how important memory is for this poet whose work is intended to safekeep a testimony of language, reviving or reinventing it in the process of performing the poem which is thought of as a new writing of the body. She doesn't place herself between the Earth and humanity like Vicuña, but between the intimacy of the body and its writing, between the kinetic reality of a body and its representation; and it is from that in-between that a new writing of the body emerges. The sound of typing takes us to the same question of bodily experience and preservation 
of language, as 'the mechanics of typewriters are the result of the body that leaves its traces on the blank page' (Urzúa 2020).

Much of the visuals from Cinco also refer to the body. Felipe Cussen introduced the pamphlet at its launch at the Chilean Museum of Contemporary Art (MAC) in August 2005. In his introduction he made reference to this exploration of the body contained in Briede's artwork: "Tanto el título como los subtítulos "Diapositiva interior” y “Tipo/bio/topo/gráficos del cuerpo", muestran la obsesión por unir el cuerpo con sus posibles representaciones: la palabra que vertebra, la fotografía que roba el alma, los mapas para perderse en las entrañas.' (Cussen 2010). The pamphlet opens with a collage in which we see two heads of the poet side by side. This duality is not capricious, as on the cover of the pamphlet two authors are credited, it reads: Anamaría Briede (2004) and Agatha Grodek (2001-2003), and then a collage between the two names which represents two triangles that look like an hourglass, one in white, the other in black, crossed by a red thread, as in the yin and yang dualism:

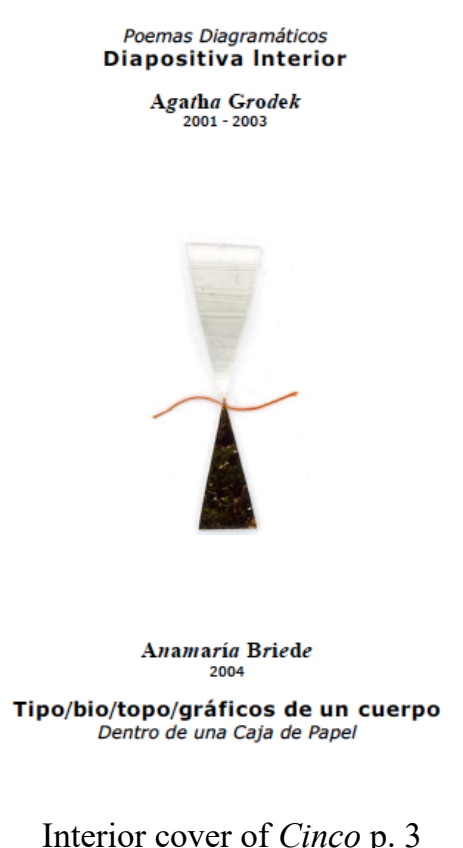

Interior cover of Cinco p. 3

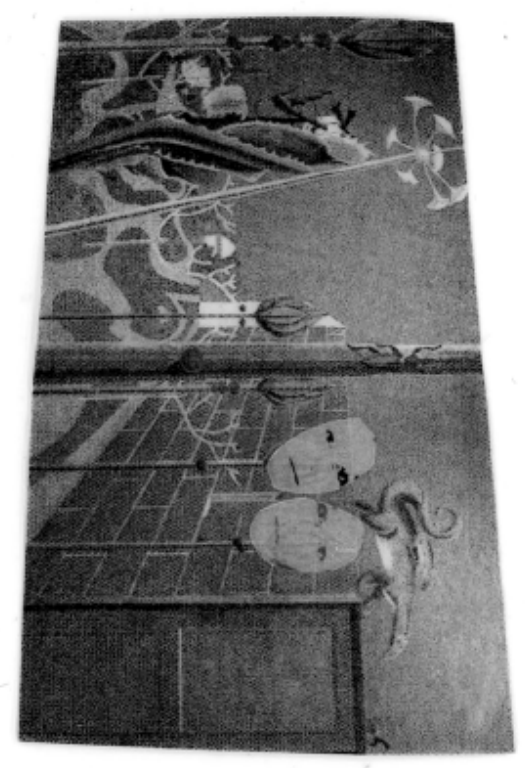

Photo collage from Cinco p. 5

Cinco maintains certain similarities with the poetics of Juan Luis Martínez, whose main publication, La nueva novela (1977), also includes two authors on the cover - although in his case they are both crossed out and in parentheses. Martínez opened up the field of poetic experimentation with his unique way of making books as collages that bring together the deepest and most philosophical questions with the most superficial and banal circumstances of humanity. The visuality, the interest in numerology and algebraic exercises used by Briede in Cinco, reminds us of some of the pieces gathered in La nueva novela, although Briede's work presents a dissociation from language absent in her predecessor. Her work is more sensual and less self-explanatory, it calls for the awakening of the senses in our body: to activate our sight, our hearing, even our sense of touch through her performances and publications, much in line with the sort of experimentation that was going on with Cobbing and company in the British Writers Forum. This is another case of a north-south connection in the sense Vicuña was pointing at when she describes her own poetics. 
In Cinco, Grodek is the alter ego of the poet, and her work is distinctively diagrammatic, more so than Briede's. Briede uses the technique of collage, photography and typing, as in 'PASEO por dentro de mi cuerpo' or 'ABCD':

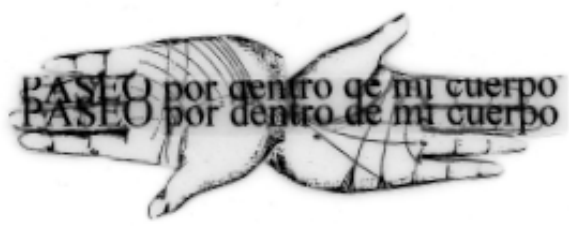

Poem collage included in Cinco p. 36

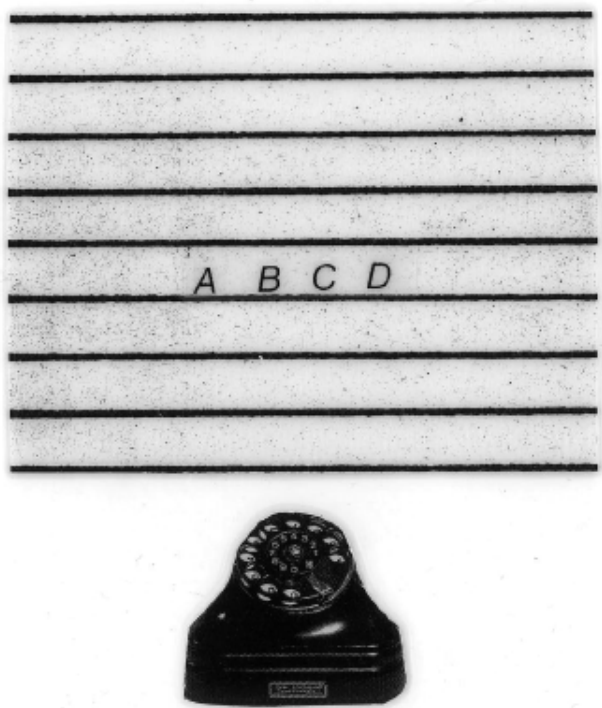

Poem collage included in Cinco p. 40

Grodek produces more typographical, linguistic, numerical and even algebraic images, as in 'cementerio de un recuerdo' and 'limpieza étnica':

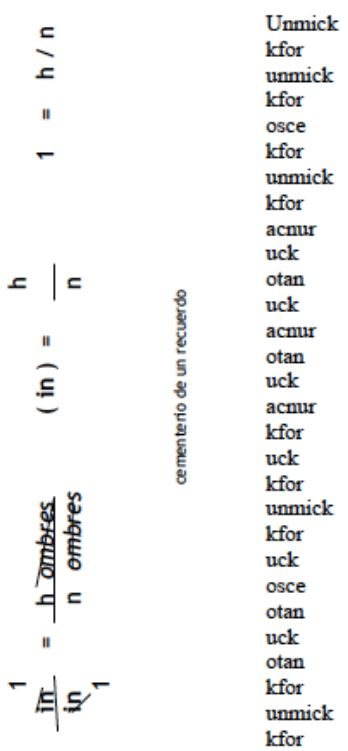


In the poem 'limpieza étnica' Briede extracts words and acronyms from the Chilean newspaper Diario el Mercurio, from an article on the Kosovo War which the author informs us was published between 1998 and 1999. When asked about this particular piece, she explains that '[1]as siglas se levantaron solas en el relato, al leerlas visualmente' (Briede, e-mail message to the author, March 29, 2021) - even the title is taken from the article following this serendipitous technique. ${ }^{3}$ One could imagine that when read aloud for the first time at one of the Foro sessions it must have had quite an impact on the audience. If we are not familiar with some of the acronyms, the sounds of Briede's performance could take us to a Dadaist experience where the words don't mean anything other than their sounds, as signifiers detached from any signified. We could even think the poet is reciting in a foreign language, considering the unfamiliarity of the sounds, which contrast with the clarity of the last sentence, 'limpieza étnica', referring to an ethnic group. It is only when we are given more clues that we can begin to decode these acronyms and get a closer understanding of the poem. These unpronounceable words clash with the final two, 'limpieza étnica', in the same way that bureaucratic language clashes with the bare bodily experience of those under attack by the cleansing.

Briede's work revolves around the experience of the body and the experience of writing in a conceptual and material/sensory way. On the one hand, she is reminding us of the importance of reimagining a new language to talk of the body and, on the other, she picks very material means to pass on that urgency. The space provided by the Foro was ideal for Briede's work, as it allowed her to elaborate on the concepts she wanted to communicate to the public in a more direct and sensorial way than through the written word. The fact that the CD has been recently rereleased is a clear indication of how her early performances at the Foro still live on in the memory of their attendees.

\section{A Performance of Dead Languages}

In the case of Luna Montenegro, the relationship with both the London Writers Forum and the Foro is crucial, as she was the connection who brought the Chilean poet Andrés Anwandter to London in the early 2000s. Andwandter, in turn, invited Martín Gubbins, founder of the Foro (Montenegro, WhatsApp audio message to the author, March 31, 2021). When she visited the Foro in Chile she was already familiar with the sessions organised by Cobbing and his wife Jennifer Pike in London. In her work, aurality takes special prominence over the written word, and the collective over the individual, so much so that she hasn't published any individual book up to this date-even though she has been invited to in various occasions, one of them by the same Foro (Montenegro, WhatsApp audio message to the author, March 31, 2021). Likewise, she normally performs collectively with her partner, the English poet and early member of the London Writers Forum Adrian Fisher, under the name Montenegrofisher or mmmmm. Even though there isn't a book or pamphlet collecting it, her work appears in numerous Writers Forum's publications and international magazines and is very well documented on the website she maintains with Fisher. ${ }^{45}$ When asked about this absence of individual publications, she manifests that she is more interested in the 'auralidad, oralidad y la

\footnotetext{
${ }^{3}$ Regarding the acronyms, 'UCK' refers to the Kosovo Liberation Army; 'ACNUR' to the United Nations High Commissioner for Refugees; 'UNMICK' to the United Nations Interim Administration Mission in Kosovo; 'KFOR' to the Kosovo Force; 'OTAN' to the North Atlantic Treaty Organisation and 'OSCE' to the Organisation for Secutity and Co-operation in Europe.

${ }^{4}$ Their website is www.mmmmm.org.uk
} 
idea de la performance, y también la idea de la presencia dentro del texto y cómo se manifiesta' (Montenegro, WhatsApp audio message to the author, March 31, 2021) than in publishing books. In this section, I will thus focus on her idea of performance and a particular connection to the languages of South America in her poetics. These languages are mostly from the south of Chile and Argentina: i.e., the Chono language from the archipelagos of Chiloé, Guaitecas and Chonos, and the Selk'nam language from the archipelago of Tierra del Fuego, in the Patagonia region, which she has visited repeatedly.

In her contribution to the Foro's collective publication Catorce/Quince (2006), we see an example of this sort of linguistic invocation. The poem doesn't have a title but starts 'Las vírgenes no saben de coñipoñi' (Montenegro et al. 2006, 70). This 'coñipoñi' places us in the island of Chiloé, as it refers to a Chilote mythological creature that looks like a worm and has the function of protecting babies-'coñi' means 'birth' and 'poñi' means 'dad'. If fed with a human mother's milk the Chilote is thought to make the child happier and calmer: a sort of nanny that assists the mother in the laborious work of nurturing the child.

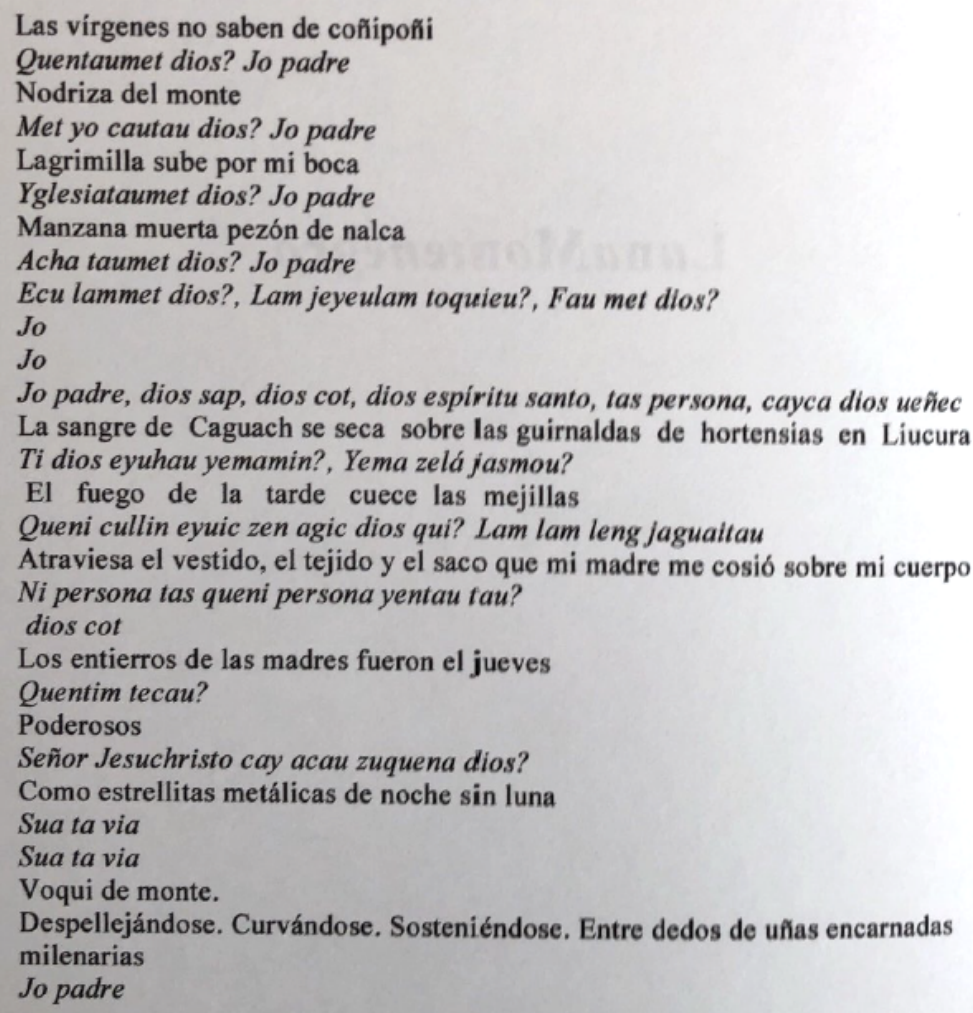

Montenegro's poem included in Catorce / Quince p. 70 


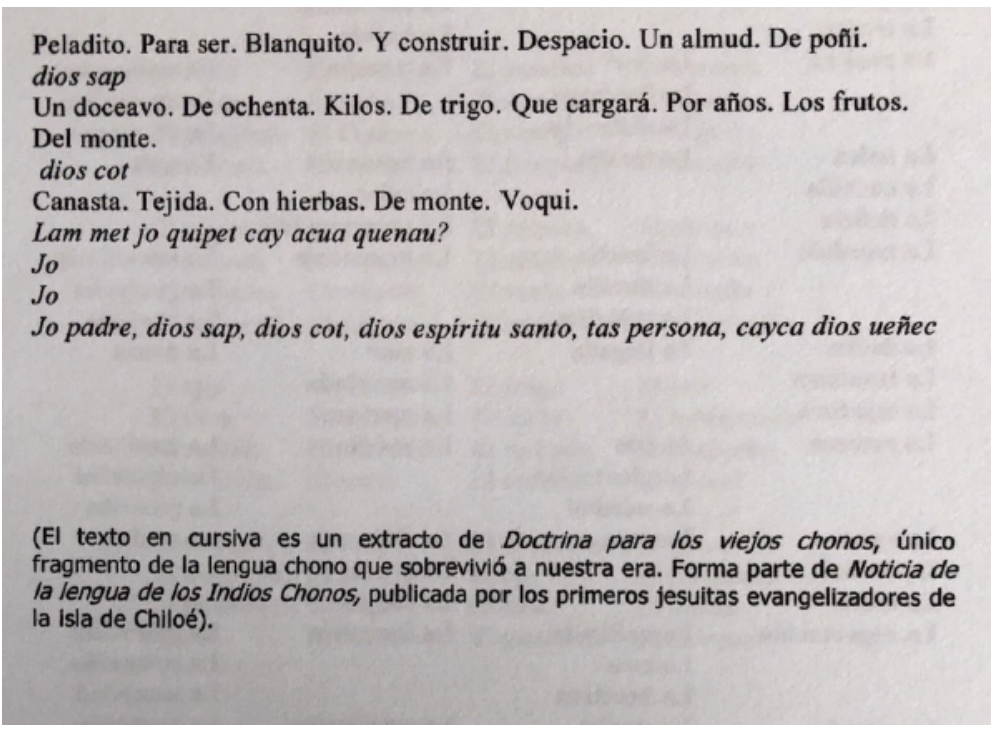

Montenegro's poem included in Catorce / Quince pp. 70-71

The whole poem alternates lines in italics written in Chono with lines in Spanish. At the end there is a note explaining that the text in italics is taken from the Jesuit text Doctrina para los viejos chonos, from the eighteenth-century, in which the last written fragment in Chono, a catechism, can be found. At the time when she wrote this piece, Montenegro had just returned from a trip to Chiloé following a friend who was undertaking research into the Chonos' culture. In an interview, Monetenegro explains how her poetry was influenced by that trip, as well as the rest of her writing. Her creative process is 'psychogeographic', meaning that she wants to rescue the experience of the landscape, of what surrounds her at the time: 'poesía como una experiencia' (Montenegro, WhatsApp audio message to the author, March 31, 2021). That's why for her lost languages aren't dead, because they have a presence that comes to life when read or performed. Talking about her particular experience with Chono, Montenegro says:

a pesar de ser una lengua muerta cuando empecé a investigar lenguajes patagónicos me di cuenta de que al leer muchas de esas palabras tenían mucha presencia, que hacían sentido a la gente a pesar de ser palabras que no conocemos, quizás esto también tiene que ver con la auralidad. (Montenegro, WhatsApp audio message to the author, March 31, 2021)

Thus, when the words are used, they acquire a sort of meaning even though we are not familiar with their literal sense, and she attributes this to aurality, to the performance of these words with our body as well as our voice.

The bits of the poem that aren't in italics address the poet's visit to Chiloé: they are full of references to the culture and history of that island, including the 'pezón de nalca' (Nalca is a local plant from the area whose flowers tips look like nipples) and 'La sangre de Caguach' (one of the small islands of the archipelago) (Montenegro et al. 2006, 70). The references are not random; on the contrary, they produce a clash with the Christian religiosity written in Chono. The sensuality and fantasy of the land and its culture contrasts with the monotonous exposition of Jesuit doctrine. Despite their efforts to transform the minds and souls of the people of the islands, the Jesuits couldn't 
eradicate their memory and ancestral rituals, here reimagined by Montenegro's poem and performance.
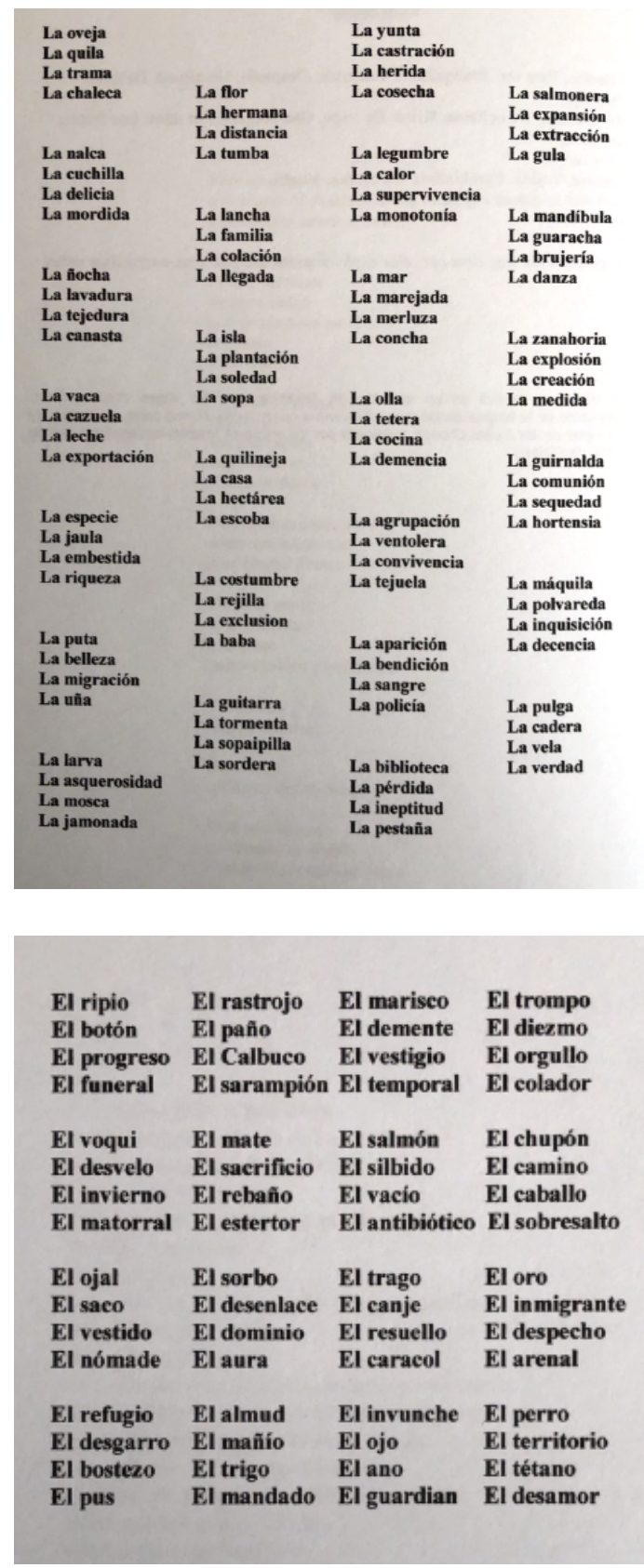

Montenegro's poem in Catorce/Quince pp. $72-73$

In the second piece included in Catorce/Quince, strong visuality brings to mind the concrete poetic experiments of the Brazilian group Noigandres, whose work often reduces language to its minimal expression: an operation that opens up the potentiality of meaning in its message. The poem has two parts, the first consists in twenty-six female nouns (hence the pronoun 'la') and the second of sixteen masculine nouns (hence the pronoun 'el') (Montenegro et al. 2006, 72-73). They recount that same trip to Chiloé with the intention of creating a history of the experience; according to Montenegro, she didn't want to give it a rhyme or a familiar poetic form. The process 
of making the poem took a week, in which each day the poet had different experiences: 'cada día tiene tres historias y cada cuatro líneas (...) son una pequeña historia' (Montenegro, WhatsApp audio message to the author, March 31, 2021), thus 'La oveja / La quila / La trama / La chaleca' (Montenegro et al. 2006, 72) is a story of its own, a direct and concrete story, reduced to its minimal expression, which translates the experience of the land: starts with the sheep, then the 'quila' (of 'esquilar', 'to shear') which is the process, the weaving, and finally the waistcoat, the final product of this process. Here, very simple elements describe for us the materiality of an important process for the people of the island, the making of clothes. She uses the popular way to refer to these materials, as in 'la chaleca', which in Spanish is normally 'el chaleco,' but is called 'chaleca' by the farmers met by Montenegro. She describes these poems as minimal stories, 'pequeñas historias aprendidas de una experiencia' (Montenegro, WhatsApp audio message to the author, March 31, 2021). The performance of these stories is thus very important, because it is when they are related that the memory of that place loaded with meaning returns, reimagined, to our presence or our present. The sedimentation produced by that particular culture, and the experience of its marks and footprints by the poet - who places herself liminally again, between the landscape and its experience, between its languages and its meanings - unravels the aurality of the Chono culture, the concrete sounds that characterize and identify their existence.

Montenegro has also been working for a long time with the Selk'nam language and its culture with the collective $\mathrm{mmmmm}$. A recent publication in a special edition of the magazine Poetry Wales (2015) dedicated to the Patagonia region is proof of that project. ${ }^{56}$ In their interest in the idea of ritual and its contemporary representations, mmmmm have produced a series of performances and films from their work about the Selk'nam people of Tierra del Fuego. Montenegro writes that she is 'interested in the performativity of the poem, in the act of naming and saying words from dead languages as a political act' (Montenegro, e-mail message to the author, December 19, 2020). Like Vicuña, Montenegro's work is highly political; in her case, she mixes lost languages with Spanish and English, or, the languages of the colonised with those of the colonisers, 'interweaving the living with the extinct' (Montenegro, e-mail message to the author, December 19, 2020) in order to produce that clash in the air Vicuña also looks for, to make the poetic experience transformative, its kinetic sounds and movements becoming an experience of memory.

\section{The Forum Cycle}

The cycle of Foro performances usually culminated in the publication of an individual or collective pamphlet carefully bound by the Chilean artist Olaya Balcells. In this laborious work the artist also transformed part of the experiences lived in the Foro sessions into art, or a memory of what took place in the workshop. Balcells designed the pamphlets with Gubbins, she thought of the shape and look they would have and made most of them by hand. According to Gubbins, '[1]os escritores son una parte de los artistas en libros como estos, hechos a mano, pero el que lo hace es otro artista, que merece tanto mérito como los primeros, sobre todo en este caso que fue todo tan laborioso, generoso y autogestionado' (Gubbins, e-mail message to the author, February 10, 2021).

\footnotetext{
${ }^{5}$ The poems can be found in the issue 'Wales, Patagonia and the cultures of the imagination,' Poetry Wales 51, no1 (summer).
} 


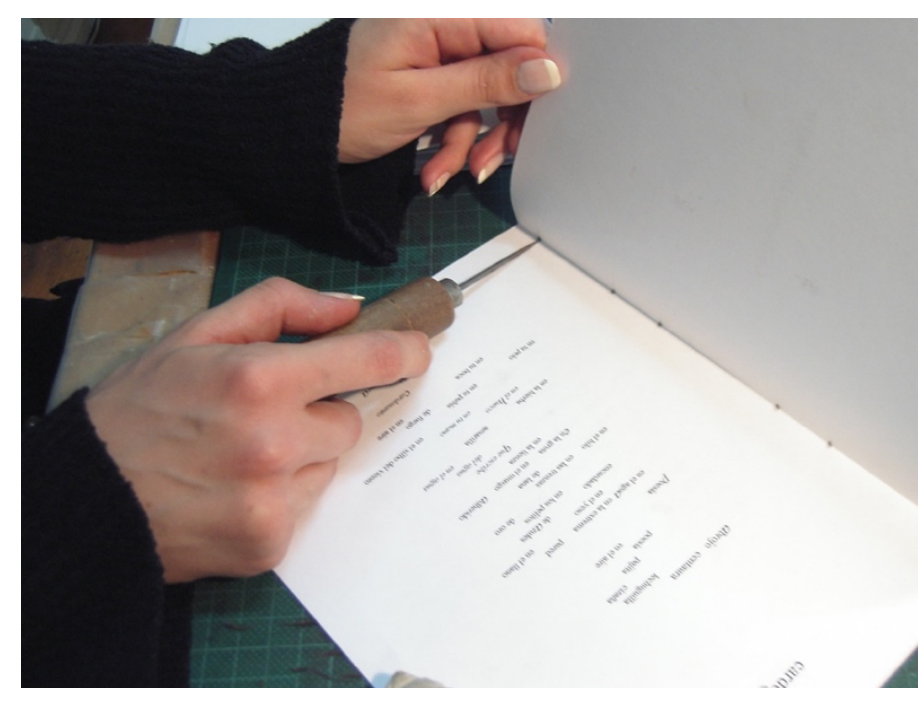

Olaya Balcells making a FDE pamphlet

The artistic cycle of both the Forum and the Foro works as an autonomous machinery that recycles memory at the same time as it documents its presence in beautiful objects, all in the margins of the book industry and museum circuits. Far from being humble, these poetics are full of power, they are pregnant with meaning, and considering they are three female poets it has been interesting to compare how their worries and expressions cross the boundaries of language and classic poetry in order to find or rencounter themselves with their ancestors, their bodies and their lost languages. They bring histories that contain different identities back to life, creating a 'historic mosaic' (Bachraty 2019, 206). We have seen that the plurality of these poems makes the work 'multiform': the plurality of meaning doesn't come from the linguistic experience of reading the poem, or not only from it; instead, it's by focusing on its aurality, when the poets perform the poem, that the work becomes most alive. The cycle, from the first performance of the poem in the session - read aloud or improvised, always a collective experience - up to its assembly and publication makes the Forums spaces of collaborative experience intrinsically linked to the poetics of the body and collective memory.

\section{Works Cited}

Alvergue, José Felipe. 2014. "Twentieth-Century Experiments in Form: A Critical ReReading of Cecilia Vicuña's Indigenism as Episteme." Comparative Literature 66, no. 2: 208-226. https://doi.org/10.1215/00104124-2682200

Bachraty, Dagmar. 2019. "Un acto de tejer y destejer la memoria. Los quipus de Cecilia Vicuña y el arte actual." H-ART. Revista de historia, teoría y crítica de arte, no. 5: 195-212. https://doi.org/10.25025/hart05.2019.10 
Burnett, Elizabeth-Jane. 2017. A Social Biography of Contemporary Innovative Poetry Communities. Cham: Palgrave Macmillan.

Bernstein, Charles, ed. 1998. Close Listening: Poetry and The Performed Word. Oxford: Oxford University Press.

Briede, Anamaría. 2005. Cinco, Columna Vertebral del Cuerpo. Santiago de Chile: FDE.

Cobbing, Bob. 1985. What the Tape-Recorder Teaches the Poet. TS. Papers of Bob Cobbing. London: British Library.

Cussen, Felipe. 2010. "Presentación Cinco de Anamaría Briede. Enumeraciones." Academia. Accessed April 7, 2021.

https://www.academia.edu/38456161/_Presentaci\%C3\%B3n_Cinco de_Anamar $\% \mathrm{C} 3 \% \mathrm{ADa}$ Briede_Blog_Foro_de Escritores 7 de febrero de 2010

Davies, Nia. 2020. “Threshold Moves: A Ritual Poetry Practice.” PhD diss., University of Salford.

Fischer-Lichte, Erika. 2008. The Transformative Power of Performance: A New Aesthetics. Translated by S. I. Jain. London and New York: Routledge.

Horáček, Josef. 2011. “Total performance: Jerome Rothenberg's Ethnopoetics Translations." Translation Studies 4, no 2: 166-182. https://doi.org/10.1080/14781700.2011.560017

Lynd, Juliet. 2015. "Los primeros sabores de Cecilia Vicuña." In Vicuñiana: El arte y la poesía de Cecilia Vicuña, un diálogo sur/norte, edited by Meredith Gardner Clark, 35-64. Santiago: Cuarto Propio.

Montenegro, Luna et al. Catorce/Quince. Santiago de Chile: FDE.

Roach, Joseph. 1995. "Culture and Performance in the Circum-Atlantic World." In Performativity and Performance, edited by Andrew Parker and Eve Kosofsky Sedgwick, 45-63. New York: Routledge.

Rothenberg, Jerome and Heriberto Yépez, eds. 2013. Eye of Witness: A Jerome Rothenberg Reader. Boston: Black Widow Press.

Rothenberg, Jerome, ed. 2017. Technicians of the Sacred: A Range of Poetries from Africa, America, Asia, Europe and Oceania. Berkeley: University of California Press.

Sheppard, Robert. 2005. The Poetry of Saying: British Poetry and its Discontents 1950 - 2000. Liverpool: Liverpool University Press.

Turner, Victor. 2017. Ritual Process: Structure and Anti-Structure. Paperback Ed. Cornell: Aldine. 
Urzúa, Macarena. 2020. “Two Typewriters Travelling across the Atlantic (Chile and the U.K.): Cecilia Vicuña's and Ana Maria Briede's Performances, Artistic and Poetic Practices". Unpublished.

Vicuña, Cecilia. 1996. Palabra e Hilo / Word \& Thread. Translated by Rosa Alcalá. Edinburgh: Morning Star Publications.

Vicuña, Cecilia. 2010. Cloud-net. New York: Art in General.

Vicuña, Cecilia. 2012. Spit Temple: The Selected Performances of Cecilia Vicuña. Translated and edited by Rosa Alcalá. Brooklyn: Ugly Duckling Press.

Vicuña, Cecilia et al. 2005. Seis. Santiago de Chile: FDE. 